\title{
Postpartum urinary retention: Evaluation of risk factors
}

\section{Postpartum üriner retansiyon: Risk faktörlerinin değerlendirilmesi}

\author{
(1) Mesut Polat ${ }^{1}$, (1) Mehmet Baki Şentürk1, (1) Çiğdem Pulatoğlu², (1) Ozan Doğan³, (1) Çetin Kılıççı \\ (1) Mehmet Şükrü Budak 5 \\ 1 İstanbul Medeniyet University Faculty of Medicine, Departments of Obstetrics and Gynecology, İstanbul, Turkey \\ ${ }^{2}$ Bayburt State Hospital, Clinic of Obstetrics and Gynecology, Bayburt, Turkey \\ 3 University of Health Sciences, Şişli Hamidiye Etfal Training and Research Hospital, Clinic of Obstetrics and Gynecology, İstanbul, Turkey \\ 4İstanbul Zeynep Kamil Women and Children's Diseases Training and Research Hospital, Clinic of Obstetrics and Gynecology, İstanbul, Turkey \\ 5 University of Health Sciences, Diyarbakır Gazi Yaşargil Training and Research Hospital, Clinic of Obstetrics and Gynecology, Diyarbakır Turkey
}

\begin{abstract}
Objective: Postpartum urinary retention means the absence of spontaneous micturition more than 6 hours after birth or when residual volume after urination is less than $150 \mathrm{cc}$. If neglected, postpartum urinary retention may result in bladder denervation and detrusor muscle weakness requiring intermittent catheterization or permanent micturition dysfunction. Our goal was to identify the possible risk factors for postpartum urinary retention. Materials and Methods: Five hundred sixty female subjects were included in this retrospective study. All data obtained including variables such as age, parity, body mass index, duration of labor, prepartum bladder catheterization were compared between female subjects with and without postpartum urinary retention. Results: Among the 560 patients recruited to our study, 124 (22.1\%) had postpartum urinary retention. Third stage duration, time from birth to the first void, and number of peripartum micturitions were found to be potential risk factors for postpartum urinary retention. Different than other studies, our study revealed a correlation between peripartum catheterization and postpartum urinary retention. There were no statistically significant differences between patients with and without postpartum urinary retention in terms of other variables. Conclusion: In this study, a correlation between peripartum catheterization and postpartum urinary retention was found. There are studies that reported the possible risk factors related to the occurrence of postpartum urinary retention. More studies should be conducted to investigate long-term results with larger populations.
\end{abstract}

Keywords: Postpartum urinary retention, postpartum bladder dysfunction, risk factors

$\ddot{0} z$

Amaç: Postpartum üriner retansiyon; doğum sonrası 6 saatlik bir sürede miktürasyonun kendiliğinden olmaması veya rezidüel idrar volümünün >150 cc'den fazla olması olarak tanımlanır. İhmal edilen postpartum üriner retansiyon, mesane denervasyonuna ve aralıklı kateterizasyon gerektiren detrusor atonisine veya kalıcı işeme disfonksiyonu neden olabilir. Amacımız, doğum sonrası üriner retansiyonun olası risk faktörlerini tanımlamaktır. Gereç ve Yöntemler: Bu retrospektif çalışmaya 560 hasta dahil edildi. Yaş, parite, vücut kitle indeksi, doğum süresi, doğum öncesi mesane kataterizasyonu gibi değişkenler dahil olmak üzere elde edilen tüm veriler postpartum üriner retansiyonu olan ve olmayan hastalar arasında karşılaştırıldı. Bulgular: Çalışmamızda 560 hastadan 124'ünde $(\% 22,1)$ postpartum üriner retansiyon saptandı. Postpartum üriner retansiyon için üçüncü evre süresi, doğumdan ilk işemeye kadar geçen süre, peripartum miktürasyon sayısı olası risk faktörleri olarak saptandı. Çalışmamız, diğer çalş̧malardan farklı olarak, peripartum kateterizasyon ile postpartum üriner retansiyon arasındaki korelasyonu ortaya koymuştur. Postpartum üriner retansiyonu olan ve olmayan hastalar arasında diğer değişkenler açısından istatistiksel olarak anlamlı farklılık bulunmadı. Sonuç: Bu çalışmada, peripartum kateterizasyon ile postpartum üriner retansiyon arasında korelasyon saptandı. Postpartum üriner retansiyon oluşumuyla ilişkili olası risk faktörlerini bildiren çalışmalar bulunmaktadır. Uzun vadeli sonuçları araştırmak için geniş popülasyonlarla daha fazla çalışma yapılmalıdır. Anahtar Kelimeler: Postpartum, postpartum üriner retansiyon, mesane disfonksiyonu, risk faktörleri

PRECIS: To identify the possible risk factors for postpartum urinary retention.

Address for Correspondence/Yazışma Adresi: Ozan Doğan, MD,

University of Health Sciences, Şişli Hamidiye Etfal Training and Research Hospital, Clinic of Obstetrics and Gynecology, İstanbul, Turkey

Phone: +90 5055060720 E-mail: ozandogan02@hotmail.com ORCID ID: orcid.org/0000-0002-0016-8749

Received/Geliș Tarihi: 10.12.2017 Accepted/Kabul Tarihi: 18.03.2018

${ }^{\oplus}$ Copyright 2018 by Turkish Society of Obstetrics and Gynecology

Turkish Journal of Obstetrics and Gynecology published by Galenos Publishing House. 


\section{Introduction}

Postpartum voiding dysfunction is defined as having difficulty in complete micturition leading to urine retention or an inability to urinate spontaneously after giving birth ${ }^{(1)}$. The exact incidence is not clear because of undiagnosed asymptomatic cases, but according to the literature, the estimated incidence of postpartum urinary retention (PPUR) has a wide range between $0.05 \%$ and $37 \%$ depending on the definitions used ${ }^{(2)}$. Overt PPUR is defined as the failure in spontaneous voiding within six hours of vaginal birth, whereas covert PPUR refers to a bladder volume of $\geq 150 \mathrm{~mL}$ remaining after spontaneous urination ${ }^{(3)}$. Although PPUR has an uncertain pathophysiology, there are several hypotheses on the cause of PPUR. Vaginal delivery can be traumatic for pelvic floor muscles and innervations, which can cause reduced bladder sensitivity. Also, peri-urethral and vulvar edema due to vaginal delivery may result in obstruction. Many prognostic factors have been identified such as mode and duration of labor, the presence of perineal trauma, the method of anesthesia or analgesia, the body mass index (BMI) of the patient, and the birth weight of the baby. The long-term effects of PPUR have not yet been identified, but many complications of persistent urinary retention due to non-delivery causes have been described. If neglected, urinary retention may result in denervation of the bladder, detrusor muscle weakness and failure, anuria, hydronephrosis, and even kidney failure caused by renal obstruction ${ }^{(4,5)}$. Whether specific treatment is unnecessary or requires intermittent catheterization may be self-limiting ${ }^{(6)}$. Screening for PPUR is not part of standard postpartum care; therefore, identifying the risk factors and early diagnosis are as important as appropriate management to prevent the potential damage of enduring retention. Our aim was to describe the possible risk factors for postpartum bladder dysfunction.

\section{Materials and Method}

We conducted a retrospective study of 560 women who have birth from January 2014 to September 2016 at a single tertiary center. The study was approved by the Ethics Committee of University of Health Sciences, Diyarbakır Gazi Yaşargil Training and Research Hospital in Turkey (approval number: 2018-30). Approval of the local ethics committee was provided for the study and the study protocol adhered to the principles of the Declaration of Helsinki. Patients who were older than 18 years and delivered via vaginal birth were included in the study. Patients who had urinary tract disease, overactive bladder, pelvic organ prolapsus or previous bladder surgery were excluded. Demographic data such as age, parity, BMI, and obstetric variables such as the use of augmentation with oxytocin or Propess ${ }^{\circledR}$, duration of active phase of labor, presence of episiotomy, degree of laceration, birth weight of the baby, number of voids during delivery, and peripartum bladder catheterization were documented and analyzed. The patients were considered as having PPUR when there was no micturition within 6 hours of delivery. For patients who were suspected as having PPUR immediately after the first micturition, residual urine volume was measured using transabdominal ultrasonography (USG) (Logiq Pro 200, 3.5 MHz convex transducer probe) and these data were documented from the patients' medical files. Estimated post voiding bladder volume was calculated using the formula, D1xD2xD3x0.9 (D1: the widest diameter in the transverse scan, D2: anteroposterior diameter in the longitudinal scan, D3: cephalocaudal diameter in the longitudinal scan $)^{(7)}$. Assessment of urinary retention during the peripartum period is difficult and there is no consensus on the amount of bladder volume that is considered as urinary retention. Generally, a normal post-micturition residual volume is accepted as $50-200 \mathrm{~mL}$ in women ${ }^{(8)}$. Bladder volume can be measured by catheterization with considerable risk of urinary infection. Transabdominal USG is a non-invasive method for the assessment of urinary retention but its accuracy may be limited especially during prepartum because of the fetus ${ }^{(9)}$. However, in this study, USG was used without this limitation because PPUR was assessed.

We defined PPUR as a failure in spontaneous voiding within six hours of birth or post void bladder volume $>150 \mathrm{~mL}$ in accordance with the literature, as verified using USG ${ }^{(10)}$. All obtained data were compared between women with and without PPUR.

\section{Statistical Analysis}

The statistical analyses were performed using the Statistical Package for the Social Sciences software, Version 17.0. Categorical data were compared using the chi-square test, Fisher's exact test, and Student's t-test for normal distribution, or the MannWhitney $\mathrm{U}$ test for those with non-normal distribution. $\mathrm{P}<0.05$ was considered statistically significant. Significant variables were analyzed by bivariate and multivariate logistic regression analyses to determine which factors were independently associated with PPUR. Odds ratio and corresponding 95\% confidence intervals are reported.

\section{Results}

Among the 560 patients recruited to our study, the mean ages

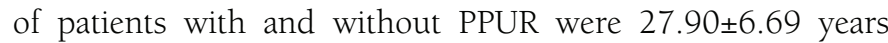
and $27.19 \pm 6.83$ years, respectively. The incidence of PPUR was $22.1 \%(n=124)$. There were no statistically significant differences between patients with and without PPUR regarding age, BMI, gravida, parity, induction with oxytocin or Propess ${ }^{\circledR}$, use of vacuum or forceps, duration of the second and third stage, fundal pressure, peripartum catheterization, number of micturitions, post-micturition residual volume, birth weight of the baby, presence of episiotomy or deep perineal laceration, and duration of the active phase. Table 1 describes the demographic data of women and labor characteristics with and without PPUR. When compared with patients without PPUR, the duration of the third stage was longer in women with PPUR $(13.57 \pm 10.31$ minutes vs. $17.02 \pm 12.93$ minutes). The number of peripartum 
micturitions was significantly higher in women without PPUR than patients with PPUR $(\mathrm{p}<0.001)$. The analyses showed that the time from birth to the first void was significantly longer in women with PPUR (661.02 \pm 1372.77 minutes vs. $212.57 \pm 80.00$

Table 1. Characteristics of patients and labor with or without postpartum urinary retention

\begin{tabular}{|c|c|c|c|}
\hline & $\begin{array}{l}\text { PPUR (-) } \\
(n=436)\end{array}$ & $\begin{array}{l}\operatorname{PPUR}(+) \\
(\mathrm{n}=124)\end{array}$ & $\mathrm{p}$ \\
\hline Age & $27.90 \pm 6.69$ & $27.19 \pm 6.83$ & $0.298 *$ \\
\hline BMI & $27.16 \pm 4.99$ & $26.74 \pm 5.24$ & $0.430^{*}$ \\
\hline $\begin{array}{l}\text { BMI group } \\
\text { Normal } \\
\text { Overweight } \\
\text { Obese }\end{array}$ & $\begin{array}{l}156(35.8 \%) \\
155(35.6 \%) \\
125(28.7 \%)\end{array}$ & $\begin{array}{l}46(37.4 \%) \\
49(39.8 \%) \\
28(22.8 \%)\end{array}$ & $0.412^{\ddagger}$ \\
\hline $\begin{array}{l}\text { Gravida median } \\
\text { (IQR) }\end{array}$ & $2(3)$ & $2(3)$ & $0.606^{\dagger}$ \\
\hline $\begin{array}{l}\text { Primiparous/ } \\
\text { nulliparous }\end{array}$ & 289/147 & $76 / 47$ & $0.355^{\ddagger}$ \\
\hline $\begin{array}{l}\text { Induction with } \\
\text { oxytocin }\end{array}$ & $191(43.8 \%)$ & $49(39.8 \%)$ & $0.432^{\ddagger}$ \\
\hline $\begin{array}{l}\text { Induction with } \\
\text { Propess }^{\circledR}\end{array}$ & $70(16.1 \%)$ & $19(15.4 \%)$ & $0.871^{\text {末 }}$ \\
\hline Augmentation & $227(52.1 \%)$ & $61(49.6 \%)$ & $0.628^{\ddagger}$ \\
\hline $\begin{array}{l}\text { Duration of active } \\
\text { phase (min) }\end{array}$ & $170.51 \pm 148.57$ & $176.90 \pm 130.91$ & $0.177^{\dagger}$ \\
\hline $\begin{array}{l}\text { Duration of the } \\
\text { second stage (min) }\end{array}$ & $34.16 \pm 37.05$ & $46.25 \pm 55.09$ & $0.055^{\dagger}$ \\
\hline Fundal pressure & $204(46.8 \%)$ & $58(47.2 \%)$ & $0.943^{\ddagger}$ \\
\hline Forceps & $23(5.3 \%)$ & $8(6.5 \%)$ & $0.599^{\ddagger}$ \\
\hline Vacuum & $9(2.1 \%)$ & $2(1.6 \%)$ & $0.551 \S$ \\
\hline $\begin{array}{l}\text { Deep perineal } \\
\text { laceration }\end{array}$ & $22(5.0 \%)$ & $10(8.1 \%)$ & $0.193^{\ddagger}$ \\
\hline Episiotomy & $266(61.0 \%)$ & $73(59.3 \%)$ & $0.739^{\ddagger}$ \\
\hline $\begin{array}{l}\text { Peripartum } \\
\text { catheterization }\end{array}$ & $242(55.5 \%)$ & $45(36.6 \%)$ & 0.001 \\
\hline $\begin{array}{l}\text { Duration of the third } \\
\text { stage (min) }\end{array}$ & $13.57 \pm 10.31$ & $17.02 \pm 12.93$ & $0.001^{\dagger}$ \\
\hline $\begin{array}{l}\text { Number of } \\
\text { micturitions } \\
\text { (min-max) }\end{array}$ & $2(0-10)$ & $2(0-6)$ & $0.001^{\dagger}$ \\
\hline Birth weight (grams) & $3228 \pm 464$ & $3203 \pm 453$ & $0.598^{*}$ \\
\hline $\begin{array}{l}\text { Postmicturition } \\
\text { residual volume } \\
(\mathrm{mL})\end{array}$ & $81.74 \pm 112.05$ & $141.32 \pm 142.22$ & $0.001^{\dagger}$ \\
\hline $\begin{array}{l}\text { Time from birth to } \\
\text { first void (min) }\end{array}$ & $212.57 \pm 80.00$ & $661.02 \pm 1372.77$ & $0.001^{\dagger}$ \\
\hline \multicolumn{4}{|c|}{$\begin{array}{l}*: \text { t-test for independent samples, } †: \text { Mann-Whitney U test, }{ }^{\ddagger} \text { : Chi-square test, §: } \\
\text { Fisher's exact test, BMI: Body mass index, IQR: Interquartile range, PPUR: Postpartum } \\
\text { urinary retention, Min: Minimum, Max: Maximum }\end{array}$} \\
\hline
\end{tabular}

minutes). No significant differences were found in terms of other variables. When the factors affecting the development of PPUR were analyzed, it was shown that a 10 minute increase in the second stage of labor led to a $6 \%$ increase in the risk of PPUR; a 1 minute increase in time from birth to the first void increased PPUR risk by $4 \%$. The absence of prepartum bladder catheterization was related to 2.2-fold increased risk of PPUR development. Given the effect of the number of peripartum voids on PPUR, an increase of one in the number of voids reduced the risk by $24.1 \%$. No statistically significant effect of other variables on the occurrence of PPUR was found (Table 2).

\section{Discussion}

We found that PPUR was relatively common with an incidence of $22.1 \%$. The reported incidence in the literature varies between $0.05-37 \%^{(2,11)}$. These differences may be due to

Table 2. Factors affecting the development of postpartum urinary retention (bivariate logistic regression)

\begin{tabular}{|c|c|c|c|}
\hline & OR & $95 \%$ CI & $\mathrm{p}$ \\
\hline Age & 0.984 & $0.954-1.015$ & 0.298 \\
\hline $\begin{array}{l}\text { BMI } \\
\text { Overweight } \\
\text { Obese }\end{array}$ & $\begin{array}{l}1.072 \\
0.760\end{array}$ & $\begin{array}{l}0.677-1.698 \\
0.449-1.285\end{array}$ & $\begin{array}{l}0.767 \\
0.305\end{array}$ \\
\hline Gravida & 1.005 & $0.911-1.108$ & 0.925 \\
\hline Nulliparity & 1.216 & $0.803-1.840$ & 0.355 \\
\hline $\begin{array}{l}\text { Induction with } \\
\text { oxytocin }\end{array}$ & 0.849 & $0.565-1.277$ & 0.432 \\
\hline $\begin{array}{l}\text { Induction with } \\
\text { Propess }{ }^{\circledR}\end{array}$ & 0.955 & $0.550-1.659$ & 0.871 \\
\hline $\begin{array}{l}\text { Duration of active } \\
\text { phase (min) }\end{array}$ & 1.0001 & 0.999-1.002 & 0.666 \\
\hline $\begin{array}{l}\text { Duration of the } \\
\text { second stage (min) }\end{array}$ & 1.006 & $1.002-1.100$ & 0.007 \\
\hline Fundal pressure & 1.015 & $0.680-1.515$ & 0.943 \\
\hline $\begin{array}{l}\text { Deep perineal } \\
\text { laceration }\end{array}$ & 1.665 & $0.767-3.618$ & 0.198 \\
\hline Episiotomy & 0.933 & $0.620-1.403$ & 0.739 \\
\hline $\begin{array}{l}\text { Prepartum bladder } \\
\text { catheterization }\end{array}$ & 2.162 & $1.431-3.267$ & 0.001 \\
\hline $\begin{array}{l}\text { Duration of the } \\
\text { third stage (min) }\end{array}$ & 1.025 & $1.008-1.042$ & 0.003 \\
\hline $\begin{array}{l}\text { Number of } \\
\text { peripartum voids }\end{array}$ & 0.759 & $0.657-0.877$ & 0.001 \\
\hline Birth weight (grams) & 1.0001 & $0.999-1.0001$ & 0.598 \\
\hline $\begin{array}{l}\text { Post-voiding } \\
\text { residual volume }\end{array}$ & 1.004 & $1.002-1.005$ & 0.001 \\
\hline $\begin{array}{l}\text { Time from birth } \\
\text { to first void (min) }\end{array}$ & 1.103 & $1.068-1.140$ & 0.001 \\
\hline
\end{tabular}

OR: Odds ratio, CI: Confidence interval, BMI: Body mass index, Min: Minimum, Max: Maximum 
different study designs and under diagnosis of covert retention. However, many of the cases remain undiagnosed and most patients with PPUR have no symptoms. The average maternal age ranges between 25 and 28 years in the literature ${ }^{(12)}$. In our study, the mean age was also within these ranges for patients with and without PPUR $(27.90 \pm 6.69$ years, $27.19 \pm 6.83$ years, respectively). The pathophysiology of PPUR is still unclear. Some physiologic, neurologic, and mechanical causes may be responsible for PPUR development. The detrusor muscle can be inhibited by the effect of increased progesterone level, thereby leading to urinary retention. Vaginal delivery can be traumatic for pelvic floor muscles and innervations, which can result in hypotonicity or reduced bladder sensitivity. Also, peri-urethral and vulvar edema due to vaginal delivery may result in obstruction ${ }^{(13,14)}$. In the literature, many risk factors have been identified for the occurrence of PPUR. The development of PPUR may be caused by prolonged stages of delivery. We found that prolonged second and third stage of labor increased the risk of PPUR, but the duration of the active phase was not associated with PPUR. A possible mechanism is applied mechanical strength, which contributes to pelvic nerve damage leading to neurologic impairment of the bladder. In some studies, the association of prolonged labor with PPUR has also been reported ${ }^{(6,12)}$. Similarly, in a study conducted by Kekre et al.,(3) it was reported that PPUR rates were higher in patients with a prolonged second stage of labor. Salemnic et al. ${ }^{(6)}$ claimed that there was a relationship between PPUR and longer second stage of birth and mediolateral episiotomy, yet this study was performed on 200 women who delivered vaginally and only once. In a larger study conducted by Yip et al., ${ }^{(12)}$ only women with vaginal deliveries $(n=691)$ were studied and it was found that a duration of delivery more than 800 minutes was significantly correlated with a rise in PPUR. In the present study, we found no relationship between parity and PPUR development. Nulliparity is usually perceived as a risk factor ${ }^{(1,14)}$. Nulliparous women are thought to be exposed to pelvic floor tenderness and pudendal nerve damage in the course of vaginal birth. The risk of developing PPUR was higher in primigravida than multigravida women in a study conducted by Liang et al. ${ }^{(15)}$. In contrast to our findings, Pifarotti et al. ${ }^{(16)}$ reported that fundal pressure was another risk factor for PPUR. Unlike our study, many studies reported that perineal damage had an impact on the development of PPUR ${ }^{(17,18)}$. A study by Musselwhite et al. ${ }^{(17)}$ revealed that second- and third-degree perineal tears, which might result in reflex urethral spasm, had a relationship with PPUR. However, in the same study, episiotomy was found to have no impact on PPUR ${ }^{(17)}$. The risk of PPUR was increased by perineal tears including sphincter rupture in a study conducted by Glavind and Bjork ${ }^{(18)}$. In contrast, Yip et al. ${ }^{(12)}$ reported that perineal trauma had no effect on the incidence of PPUR.

Contrary to other authors ${ }^{(3,19)}$, we detected no association between vaginal operative birth and PPUR. Vaginal operative delivery can be confused with other factors such as longer delivery, epidural analgesia, parity and episiotomy, and causes debates regarding whether it is an independent predictor ${ }^{(1)}$. Several studies, as well as ours, have shown that fetal birth weight does not increase the risk of PPUR ${ }^{(8,20)}$. Conversely, it has been reported that PUR was also due to infant birthweight lower than $3800 \mathrm{~g}^{(14)}$. In our study, we did not document the follow-up of the patients. In a study by Carley et al., ${ }^{(11)} 11.332$ women were evaluated following vaginal delivery and it was found that $45 \%$ of symptomatic PPUR resolved within 48 hours and $25 \%$ of women had persistence for more than 72 hours. Various short-term complications of PPUR have been identified, but it is not certain whether PPUR is related to any long-term morbidity. Women with PPUR were not significantly different from those without PPUR in the study by Yip et al., ${ }^{(21)}$ which was a four-year follow-up about women with PPUR, using outcome variables such as urinary stress incontinence, fecal incontinence, frequency, nocturia, urgency, urge incontinence, and coital incontinence. In a larger study, it was reported that $0.05 \%$ of PPUR had persisted related to long-term bladder dysfunction $^{(19)}$. There is no consensus on the significance of PPUR ${ }^{(22)}$. Furthermore, guidelines do not recommend routine bladder scanning for the diagnosis of PPUR, due to the size of the uterus after delivery, and the accuracy of USG measurements of residual volume is debatable ${ }^{(23,24)}$. More research is needed to confirm the benefits and cost-effectiveness of post-routine bladder screening. The present study demonstrates that the PPUR development rate is lower in patients who had peripartum bladder catheterization. There are many studies in the literature reporting the possible risk factors related to the occurrence of PPUR, but most do not mention peripartum bladder catheterization, which makes it difficult to compare them with results in terms of the effect of catheterization on the development of PPUR. To the best of our knowledge, this is the first study to define the relationship between peripartum catheterization and the development of PPUR.

\section{Study Limitations}

One of the limitations of the study is it's retrospective and the small number of cases. Another point is that it did not include volumes of voiding or oral intake of the women.

\section{Conclusion}

In conclusion, PPUR is a relatively common problem that can lead to irreversible damage to the bladder. Further prospective studies with more participants are needed to support the findings and define long-term implications of PPUR for detecting, avoiding, and managing postpartum voiding dysfunction.

\section{Ethics}

Ethics Committee Approval: The study was approved by the Ethics Committee of University of Health Sciences, Diyarbakır Gazi Yaşargil Training and Research Hospital in Turkey (approval number: 2018-30). 
Informed Consent: Consent form was filled out by all participants.

Peer-review: Externally peer-reviewed.

\section{Authorship Contributions}

Surgical and Medical Practices: M.P., O.D., Concept: M.P., M.B.Ş., Design: Ç.P., O.D., Data Collection or Processing: M.B.Ş., Ç.K., M.Ş.B., Analysis or Interpretation: O.D., M.Ş.B., Literature Search: M.P., O.D., Ç.K., Writing: Ç.P., O.D.

Conflict of Interest: No conflict of interest was declared by the authors.

Financial Disclosure: The authors declared that this study received no financial support.

\section{References}

1. Mulder FE, Schoffelmeer MA, Hakvoort RA, Limpens J, Mol BW, van der Post JA, et al. Risk factors for postpartum urinary retention: a systematic review and meta-analysis. BJOG 2012;119:1440-6.

2. Buchanan J, Beckmann M. Postpartum voiding dysfunction: identifying the risk factors. Aust N Z J Obstet Gynaecol 2014;54:415.

3. Kekre AN, Vijayanand S, Dasgupta R, Kekre N. Postpartum urinary retention after vaginal delivery. Int J Gynaecol Obstet 2011;112:1125.

4. Mustonen S, Ala-Houhala IO, Tammela TL. Long-term renal dysfunction in patients with acute urinary retention. Scand J Urol Nephrol 2001;35:44-8.

5. Zaki MM, Pandit M, Jackson S. National survey for intrapartum and postpartum bladder care: assessing the need for guidelines. BJOG 2004;111:874-6.

6. Salemnic Y, Gold R, Toov JH, Jaffa A, Gordon D, Lessing J, et al. Prevalence, obstetric risk factors and natural history of asymptomatic postpartum urinary retention after first vaginal delivery - a prospective study of 200 primipara women. J Urol 2012;187(Suppl):788.

7. Poston GJ, Joseph AE, Riddle PR. The accuracy of ultrasound in the measurement of changes in bladder volume. Br J Urol 1983;55:3613.

8. MacLean AB, Cardozo L. Incontinence in Women - Study Group Statement. London: Royal College of Obstetricians and Gynaecologists Press; 2002.p.433-41.

9. Gyampoh B, Crouch N, O'Brien P, O'Sullivan C, Cutner A. Intrapartum ultrasound estimation of total bladder volume. BJOG 2004:111:103-8.
10. World Health Organization. World Health Organization Technical Consultation on Postpartum and Postnatal Care. Geneva: World Health Organization; 2010.

11. Carley ME, Carley JM, Vasder G, Lesnick TG, Webb MJ, Ramin KD. Factors that are associated with clinically overt postpartum urinary retention after vaginal delivery. Am J Obstet Gynecol 2002;187:4303.

12. Yip SK, Brieger G, Hin LY, Chung T. Urinary retention in the postpartum period. The relationship between obstetric factors and the post-partum post-void residual bladder volume. Acta Obstet Gynecol Scand 1997;76:667-72.

13. Teo R, Punter J, Abrams K, Mayne C, Tincello D. Clinically overt postpartum urinary retention after vaginal delivery: a retrospective case-control study. Int Urogynecol J Pelvic Floor Dysfunct 2007;18:521-4.

14. Lim JL. Post-partum voiding dysfunction and urinary retention. Aust N Z J Obstet Gynaecol 2010;50:502-5.

15. Liang CC, Chang SD, Chang YL, Chen SH, Chueh HY, Cheng PJ. Postpartum urinary retention after cesarean delivery. Int J Gynaecol Obstet 2007;99:229-32.

16. Pifarotti P, Gargasole C, Folcini C, Gattei U, Nieddu E, Sofi G, et al. Acute post-partum urinary retention: analysis of risk factors, a casecontrol study. Arch Gynecol Obstet 2014;289:1249-53.

17. Musselwhite KL, Faris P, Moore K, Berci D, King KM. Use of epidural anesthesia and the risk of acute postpartum urinary retention. Am J Obstet Gynecol 2007;196:472.

18. Glavind K, Bjork J. Incidence and treatment of urinary retention postpartum. Int Urogynecol J Pelvic Floor Dysfunct 2003;14:11921.

19. Groutz A, Hadi E, Wolf Y, Maslovitz S, Gold R, Lessing JB, et al. Early postpartum voiding dysfunction: incidence and correlation with obstetric parameters. J Reprod Med 2004;49:960-4.

20. Rizvi RM, Khan ZS, Khan Z. Diagnosis and management of postpartum urinary retention. Int J Gynaecol Obstet 2005;91:71-2.

21. Yip SK, Sahota D, Chang AM, Chung TK. Four-year follow-up of women who were diagnosed to have postpartum urinary retention. Am J Obstet Gynecol 2002;187:648-52.

22. Shah JPR, Dasgupta P. Voiding difficulties and retention. Clinical Urogynaecology, 2nd edn. London: Churchill Livingston; 2000.p.259-72.

23. Routine Postnatal Care of Women and their Babies. National Institute for Health and Clinical Excellence Guideline 37. London; 2006.

24. World Health Organization. World Health Organization Technical Consultation on Postpartum and Postnatal Care. Geneva: World Health Organization; 2010. 